$\begin{array}{ll}\text { Variants } & \begin{array}{l}\text { Variants } \\ \text { The Journal of the European Society for Textual } \\ \text { Scholarship }\end{array}\end{array}$

15-16 | 2021

Textual Scholarship in the Twenty-First Century

\title{
Some Answer Poems and their Manuscript History: Jonson, Herrick, and the Circulation of Verse
}

\author{
Mark Bland
}

\section{Q OpenEdition \\ Journals}

Electronic version

URL: https://journals.openedition.org/variants/1269

DOI: 10.4000/variants. 1269

ISSN: 1879-6095

\section{Publisher}

European Society for Textual Scholarship

Printed version

Date of publication: 1 July 2021

Number of pages: 155-173

ISSN: 1573-3084

\section{Electronic reference}

Mark Bland, "Some Answer Poems and their Manuscript History: Jonson, Herrick, and the Circulation of Verse", Variants [Online], 15-16 | 2021, Online since 01 July 2021, connection on 16 July 2021. URL: http://journals.openedition.org/variants/1269 ; DOI: https://doi.org/10.4000/variants.1269 


\title{
Some Answer Poems and their Manuscript History: Jonson, Herrick, and the Circulation of Verse
}

Mark Bland

\begin{abstract}
This article uses manuscript sources and stemmatics to illuminate the history of the three answer poems that are discussed. The first example from Ben Jonson shows how he repeatedly tinkered with the text of a poem he wrote in answer to Sir William Burlase. The second example demonstrates that "Of Inconstancy" is an exchange between Jonson and Sir Edward Herbert, thereby adding a new poem to Jonson's canon. The third example illustrates how Robert Herrick took a poem by another and then altered it to write a polemic against it. In both the last two cases, the article resolves issues of uncertain authorship.
\end{abstract}

THE CIRCULATION OF MANUSCRIPT POETRY in the early-mid seventeenth century was closely linked to notions of conviviality and civility; even if, sometimes, a poem might invite a trenchant answer. Hence, the texts in any miscellany reflect both personal taste and an interest in the broader social conversation to which those texts were connected. That sense of engagement with the literary utterance extended to the composition of poems in response to others that were in circulation. Sometimes answers were direct and personal, sometimes they were exercises in wit, and sometimes they were deliberately public responses to a text that was either in circulation or to a text to which the person concerned had had access. All these different kinds of answer poetry are to be found in the examples that are to be discussed presently.

In an important article on answer poetry, Scott Nixon made the point that certain poems invited a direct engagement with their concerns either through the style of their argument, or through the way in which they allowed for debate and even parody (Nixon 1999). Such poems are quite different in tone and intention from those written in more than one voice, such as Jonson's "Epode" (Forrest xI) or "A Musicall Strife" (Underwood 3), where the debate is the poem 1 The obvious corollary to this is that authors usually did not answer their own poems. Nevertheless, there are examples where both the original and

1 The numbering of the Epigrammes and The Forrest was established by Jonson, and has been followed by all modern editors; that for The Underwood is the accepted convention followed by both Simpson (Oxford: 1925-52) and the Cambridge editors (Bevington et 2013), as well as for the forthcoming Oxford edition. 
the answer poem have been attributed to the same author; and others where a single "text" has merged both the proposition and the answer. In both cases, there are clearly attribution and identity issues to resolve, and it is here that stemmatic analysis may help by providing evidence of the relationship between transmission, revision, and response - and thus issues of origin and authorship.

The point about stemmatic analysis is that maps of transmission do not only establish how specific copies of a text are related and through which networks they passed: they also cumulatively map how miscellanies were pieced together. Thus, it is particularly useful if multiple texts by different authors are collated and analysed as this adds precision and complexity to the study of the social networks within which the texts are located. It is for that reason that scholars have begun to realize that the scribal networks of manuscript circulation in the early modern period are more informative and significant than had been assumed (Bland 2013). Since most of the work that has been done involving manuscript transmission has been concerned with the poetry of Donne, the mapping of textual transmission for other authors such as Jonson, Roe, Beaumont, Herrick, Strode and Randolph could offer further insight into the social networks that a single author study obscures. This is especially so when answer poems are concerned, because they are by their nature multiple author texts. Hence, what was once dismissed as the corrupt residue of literary fashion is now understood as an important by-product of, and witness to, the histories of revision, transmission, and reception. This, in turn, has led to a renewed interest in the miscellanies and their relationship with one another.

The following discussion will turn first to two examples from Jonson, including a previously unattributed poem, and then to one that as been attributed to Herrick but is not by him. Jonson and Herrick are useful counterpoints to Donne as their initial entry into circulation occurs at different stages in the transmission process to each other and, thus, as witnesses to the history of the underlying documents they do not duplicate the patterns of circulation. That broader matter, however, of how multiple authors may be used to interpret a manuscript's history is beyond the scope of the present article. For now, it will suffice to resolve the more specific issues of authorship and the circulation of these poems and thus lay the foundation for future work.

\section{I}

Jonson's exchange with Sir William Burlase (Underwood 52; see Figure 1) is both one of his most appealing poems, and a classic example of the "answer poem" genre. For all its brevity and simplicity, it is beautifully pitched between selfeffacing irony and genial praise. Both Burlase and Jonson suggest that their own command of their mistresses, Art and Poetry, are inadequate to do their praise for the other justice. Burlase was a friend of Dudley Carleton and John Chamberlain (a member of parliament), and he painted for pleasure. He modestly suggests that because he had less than "half" of Jonson's art, he will never be able to truly 
capture Jonson's "worth" to his friends and their admiration of him. Jonson answers by drawing on the Senecan notion that true benefits are reciprocal. He mocks his own obesity by suggesting that a "blot" would be quite sufficient to portray him, and laments that as a poet he only has the black and white of the page, and not the full colour palette of the painter. This allows Jonson to open up the distinction between his claim to honesty and the "flatt'ring Colours and false light" of the painter. He ends by returning the ample praise of his friend: conviviality, modesty, and the reciprocation of admiration are the true benefits that are shared in their exchange, and hence the poems epitomize the friendship between the two men.

Jonson clearly identifies Burlase as the author of the poem that he answers, and hence it has been accepted into editions of Jonson's poetry as the contextual material against which the answer ought to be understood. There are eleven manuscript copies of the poem to Burlase, as well as the text in the 1640 Workes, the two Benson piracies (the Execration upon Vulcan and Horace his Art of Poetry, both published in 1640), and another copy in Parnassus Biceps (Wing W3686 1656, $\left.C 7^{\mathrm{r}-\mathrm{v}}\right)$. At no time does Burlase's initial poem circulate separately from Jonson's answer. Two witnesses, Bodleian Library Rawlinson Poetry MS 142 (11.1-15) and Parnassus Biceps, have Jonson's answer only. These two "answer only" versions descend from different lines within the first state of the poem. Among the other witnesses, Edinburgh University Library MS Dc.7.94 is a manuscript copy of the printed Benson duo-decimo piracy, and Bodleian Library English Poetry MS c.50 is very corrupt and omits the first six lines of Jonson's poem. As elsewhere, the Benson piracies conflate stolen sheets from the 1640 Workes with an earlier manuscript version. The sigla used in the stemmatic diagram (see Figure 2) combines the STC location symbol for the library (i.e. $\mathrm{L}=$ London), with the first letter(s) of the manuscript series (e.g. A = Additional), and the full manuscript number.

The recent Cambridge Jonson edition (Bevington et al. 2013) did not attempt textual reconstructions of this kind. The stemma demonstrates that Jonson tinkered with the poem and revised it four times. One of the revisions was to line 4 of the poem by Burlase, where "the trier" was altered to "will tire": this alteration must have been made by Jonson around the time of the death of Burlase, as it occurs only in the Newcastle manuscript (LH4955), and the three editions printed in 1640. The same line of recension also alters line 18 of Jonson's text, substituting "form'd" for "drawne". The other principal revisions affect lines 1, 12, 15, 21 and 24 of Jonson's answer, and it is the gradual evolution of these that separates the earlier stages of revision.

The original tradition, as it was circulated, survives through seven witnesses, and has twenty-three small-scale variants that document the history of its reception: of these, one group of three manuscripts reads "What" as the first word of the poem while the rest, through all lines of descent, read "Why". The "What" group includes the fifteen-line Jonson-only fragment, Rawlinson Poetry MS 142. The other two manuscripts (Yale Osborn MS b200, and British Library Harley 
A Poëme sent me by Sir WILLIAM BurLase.

The Painter to the Poët.

$\mathrm{T}^{\circ}$ o paint thy Worth, if rightly I did know it, And were but Painter halfe like thee, a Poët; BEN, I would show it:

But in this skill, m'unskilfull pen will tire, Thou, and thy worth, will still be found farre higher; And I a Lier.

Then, what a Painter's here? or what an eater Of great attempts! when as his skil's no greater, And he a Cheater?

Then what a Poet's here! whom, by Confession Of all with me, to paint without Digression

There's no Expression.

My Answer. The Poèt to the Painter.

W HY? though I seeme of a prodigious wast, I am not so voluminous, and vast, But there are lines, wherewith I might b'embrac'd.

'Tis true, as my wombe swells, so my backe stoupes, And the whole lumpe growes round, deform'd, and droupes, But yet the Tun at Heidelberg had houpes.

You were not tied by any Painters Law To square my Circle, I confesse; but draw My Superficies: that was all you saw.

Which if in compasse of no Art it came To be described by a Monogram, With one great blot, yo'had form'd me as I am.

But whilst you curious were to have it be An Archetipe, for all the world to see, You made it a brave piece, but not like me.

$\mathrm{O}$, had I now your manner, maistry, might, Your Power of handling, shadow, ayre, and spright, How I would draw, and take hold, and delight.

But, you are he can paint; I can but write: A Poet hath no more but black and white, Ne knowes he flatt' ring Colours, or false light.

Yet when of friendship I would draw the face, $\Lambda$ letter'd mind, and a large heart would place To all posteritie; I will write BURLASE.

Figure 1: Ben Jonson, "A Poeme sent mee by Sir William Burlase", Workes (1640), 2G3v $-4^{\mathrm{r}}$. 
MS 6931) are united by the variants of "be" for "are" in line 3, "had" for "haue" in line 15 and "I'de" for "I would" in line 24. The Rawlinson manuscript has the correct reading "haue" in line 15 and is further distinguished by reading " $\mathrm{w}^{\text {th }} \mathrm{w}^{\text {ch }} \mathrm{I}$ am" for "wherewith I may" in line 3. On the other side of this line of descent, Folger V.a.97 and Parnassus Biceps are united by "of" for "at" in line 6 and the "but" of "describ'd but by" in line 11, whilst British Library Harley MS 6917 reads "be [...] by which I may" in line 3 and "while" for "whilst" in line 11. The final manuscript, Bodleian MS Eng. Poet c.50 has multiple corrupt readings as well as lacking the first six lines of Jonson's answer, but it does read both "whilst" and "describ'd by" thereby indicating a further line of transmission within this group.

Jonson's first revision was to lines 15 and 18, replacing "Y'haue made" with "You made" and the passive "draw, behold, and take delight" with the more active "draw, and take hold, and delight". This tradition has two extant descendants (British Library Sloane MS 1792 and Additional MS 30892), a sibling of thee latter of which was used to "correct" the stolen sheets of the 1640 Workes that were used as copy for the Benson piracies, changing "Yet" to "But" in line 22 and reverting to "I would write" for "I will" in line 24. Both these witnesses have the variant "drawe" for "drawne" in line 12, with the Sloane manuscript reading "bee" for "are" in line 3 and "Yet" in line 22.

Jonson then made three further revisions by the mid-1620s. The first was to alter the fourth word of the first line from "Why? Though I be of a prodigious wast" to "Why? though I seeme [...]"; In line 12 "With one great blot yo'haue drawne me as I am" was altered to " $y$ 'had drawne"; and in line 24, "I would write Burlase" was rendered absolute with "I will write [...]". Only Leeds Archives MS MX237 exists in this state. The Newcastle manuscript then alters line 4 of the Burlase poem to "will tire" and "Ne" for "Nor" in line 21. The final revision of the poem for the 1640 Workes involved a further tweak to line 12 with "drawne" altered to the more physical "form'd".

The final issue involves the history of the Benson piracies. Here, as elsewhere, the piracies are demonstrably a conflation of stolen sheets of the 1640 Workes emended by reference to another manuscript source, in this case a relative of British Library Additional MS 30982. Hence, the Benson texts have the final readings "will tire", "form'd", "You made", "draw, and take hold, and delight", and "Ne". combined with "But" in line 22 and "I would" in line 24: a fact indicative of their conflated status. This is recorded by the dotted line that links them with their source.

What this stemma illustrates is the history of an evolving text that is circulated early on and was then revised on multiple occasions with seemingly minor adjustments. Under the circumstances, corruption is only one part of the issue, for the history of the poem is as much horizontal across the tradition as it is vertical within each state. To edit the poem without a sense of this evolution, as the Cambridge edition does, failing to separate revision from error for those variants listed in the commentary, is a dereliction of editorial responsibility. 


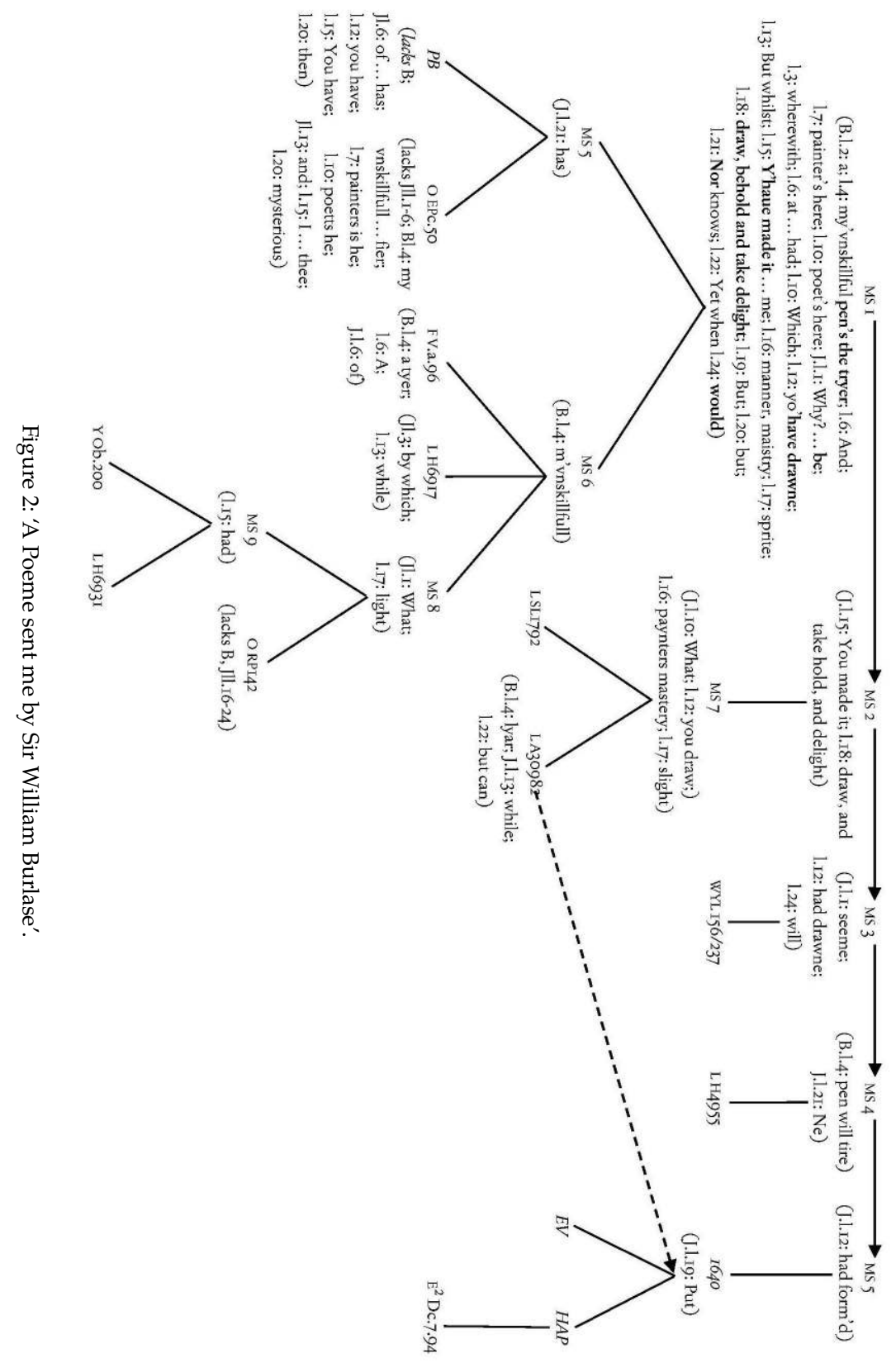




\section{II}

If the Burlase exchange is an obvious example of the answer poem, another, "Of Inconstancy", is quite the opposite. It is found in three manuscripts: the siblings British Library Harley MS 4064 and Bodleian Library Rawlinson Poetry MS 31, and in University of Nottingham Portland MS Pw V37. In the Rawlinson and Harley manuscripts the poem is laid out as a single text; it is only in the Portland manuscript that the stanzas are divided by the subtitle, "The Aunswere, in praise of it". This copy of the poem was not known when it was last discussed in connection with the poems of Edward, Lord Herbert of Cherbury in the early twentieth century (Moore Smith 1923, 119 and 167-68).

Most of the poems of Edward Herbert were printed for the first time some seventeen years after his death, in 1665 (Wing H1508). There exists, as well, an important manuscript of the poems with corrections in Herbert's hand (British Library Additional MS 37157), and there are a number of other poems that survive only in manuscript copies (Beal 1980, II: 167-68). The most recent edition was prepared shortly before the First World War, though it was published in 1923. The editor, Moore-Smith, based it on the 1665 text because, he argued, "the printed book is based on a manuscript which represented Herbert's second thoughts" (Moore Smith 1923. xxvii). Moore Smith's edition is generally a good one, and he certainly knew of Herbert's corrected copy. He also collated some of the more obvious coterie manuscripts, though he did not do so thoroughly. Instead of using British Library Harley MS 4064, he printed several poems that had not been included in 1665 from Bodleian Rawlinson Poetry MS 31, and he treated one of them, "Of Inconstancy" as dubia.

In Rawlinson Poetry MS 31, the text is copied on $\mathrm{f} .36^{\mathrm{r}}$ with the title, and the attribution, "Sir Edw̄: Harbert". It reads:

Inconstancy's, the greatest of synns

It neyther endes well, nor beginns

All other ffaultes, wee simplye doe

This 'tis the same ffaulte, and next to:

Inconstancye, noe synn will proue

yf wee consider that wee Love

But the same beautye in another fface

lyke the same Bodye, in another place:/

Moore-Smith did not record the Harley manuscript, or its variants, and must have overlooked it. Instead, he reproduced the above with some minor adjustments, and noted in his commentary that "Perhaps they [the lines] are by two authors - the second stanza being an answer to the former. In this case it is the answer one would assign to Lord Herbert" (Moore Smith 1923, 167). His guess, of course, was to be proved by the Portland manuscript. 
The copy of "Of Inconstancy" in Harley $4064 \mathrm{f} .259^{\mathrm{v}}$ is in the hand of the second scribe, who is not particularly careful - although he is less idiosyncratic in his spelling than the Feathery scribe, who prepared Rawlinson Poetry 31 (Beal 1998). On the whole, the second Harley scribe punctuates less heavily, though he does record a comma after "This" in line four, implying that there should be a colon after "doe", a period after "beginns", and a semi-colon after "synns". Other minor adjustments include the reading "too" at the end of line four, the words "loue" (1.6) and "body" (1.8) with an initial lower case, and the absence of the initial double " $\mathrm{ff}$ " that is characteristic of Feathery. The most substantial difference is in the first line, which the second Harley scribe reduces to a regular tetrameter at the expense of the meaning of the poem. As well as removing "of", he introduces a hyphen into "Inconstancy":

In-constancy the greatest sins It neither ends well, nor beginns

All other faults wee simply doe

This, tis the sam fault and next too

Inconstancy no sinn will proue

If wee Consider that we loue

But the same bewty in another face

like the same body in another place.

The final manuscript unknown to Moore-Smith came from Welbeck Abbey. On the whole, the text of Nottingham MS Pw V37 p.204 is better than that found in the Rawlinson-Harley pair, though too many words have an initial capital. This suggests that there may be a lost intermediary between the answer as it first circulated and the copy that is preserved in this source. In line three, the Portland manuscript has the obviously correct reading "singly" instead of "simply", as it is found in the other pair; and in line four, it reads "first", where the other tradition has the weaker "same"; elsewhere, the reading "Inconstancy is", in the first line, renders the verse as a regular pentameter. Most importantly, the manuscript demonstrates that Moore-Smith's hunch was correct, and that the two stanzas are separate poems:

\section{Of Inconstancy}

Inconstancy is $\mathrm{y}^{\mathrm{e}}$ greatest of Sinnes;

Itt neither Ends well, nor beginnes:

All other Faults Wee singly doe,

This is $\mathrm{y}^{\mathrm{e}}$ first Fault, and Next too.

The Aunswere, in praise of it

Inconstancy, noe sinne will proue

If wee consider $\mathrm{y}^{\mathrm{t}}$ wee loue

But $\mathrm{y}^{\mathrm{e}}$ same Beauty in another face

Like $y^{\mathrm{e}}$ same Body, in another place. 
This version makes it possible to resolve the problem of attribution, for there is nothing unusual about a poem being circulated with an answer to it in verse miscellanies of the period (Hart 1956. Nixon 1999). With the support, therefore, of Rawlinson Poetry 31, and the judgment of Moore Smith, the "Aunswere" may safely be attributed to Herbert. This leaves the question as to who wrote the other four lines of the text.

On external grounds alone, Jonson would have to be considered a likely candidate as author of the epigram. At the end of the first decade of the seventeenth century, he was obviously closely involved with Herbert: his epigram to Herbert, Herbert's dedication of the satire "Of Travellers" to Jonson, the gift by Herbert to Jonson of a copy of Tertullian, and the manuscript of Biathanatos, are all indicative of Herbert having become an intimate part of Jonson's literary circle ${ }^{2}$ This is re-inforced by the arrangement of Harley 4064 and Rawlinson Poetry 31. In Harley 4064, the poem is part of a sequence that includes Jonson's verse letter to Sir Robert Wroth in praise of a country life, followed by Donne's "Twickenham Garden", followed by the epigram and its answer, followed by Donne, Jonson, and then Herbert on the death of Cecilia Bulstrode. With Rawlinson Poetry 31, the two Donne poems have been removed, leaving the Jonson and Herbert poems as a sequence together.

When "Of Inconstancy" is read against Jonson's other epigrams, style, sentiment, subject matter, and metre, all cohere to identify his hand. The idea of constancy and fortitude as manly virtues that require a Stoic centredness, are to be found throughout the poems. Sir John Roe, for instance, is one who has endured "His often change of clime (though not of mind)" (Epig. 32); William Roe is reminded that "Delay is bad, doubt worse, depending worst", and Jonson goes on to add "Each best day of our life escapes vs, first" (Epig. 70); Sir Henry Goodyere is complimented for his "wel-made choise of friends, and bookes" (Epig. 86); Sir Thomas Roe is told "He that is round within himselfe, and streight, | Need seeke no other strength, no other height" (Epig. 98); and Herbert is praised for "Thy standing vpright to thy selfe" (Epig. 106). If the theme is insistent, there are other echoes as well that are more subtle, but which show the same turn of mind, whether it be "Th'expence in odours is a most vaine sinne" (Epig. 20), or the structure and rhythm of the final couplet to Sir Henry Savile (Epig. 95):

Although to write be lesser then to doo,

It is the next deed, and a great one too.

Even if, on internal evidence alone, one might hesitate (it is, after all, a short poem), what makes the attribution convincing is that the literary judgments about style and substance combine with the evidence from the Portland manuscript that the two stanzas are two poems, and the fact that the Rawlinson-

2 The copy of Tertullian's Opera (Franeker, 1598) is at Charlecote House, Warwickshire, shelfmark L6-22; the manuscript of Biathanatos is Bodleian Library, Oxford, MS e Musaeo 131 (Bland 1998). 
Harley pair of manuscripts are so clearly identifiable with the verse of Donne, Jonson, and Herbert. The poem is not by a later imitator, nor is it characteristic of Donne or Sir John Roe, but rather it has much in common with a group of early fragments by Jonson, on "Murder", "Peace", and "Riches", that are to be found in Englands Parnassus (STC 378-80 1600, P2 ${ }^{\mathrm{r}}, \mathrm{Q}^{\mathrm{v}}-3^{\mathrm{r}}, \mathrm{S} 1^{\mathrm{v}}$ ). It ought not be surprising that from time to time Jonson might sketch out an idea, or that friends might engage in a little literary bandinage.

Hence there are, perhaps, three reasons why Jonson may have chosen not to preserve this poem: first, if Jonson had started early on with the idea of writing epigrams about abstract moral ideas, it is a stage that he developed through, and it is possible he cannibalized much of this material for his Epigrammes. Second, the poem and its answer do not particularly fit either the Epigrammes or the Forrest, and it is evident elsewhere that Jonson did not include a number of his early poems for this reason. Third, Jonson regularly treated of the theme elsewhere, and he may have felt that these four lines were rather a sketch that might be regarded as unfinished. If Jonson had intended a longer meditation on inconstancy, for instance, then the next logical step would have been to turn the poem towards the praise of patience, fortitude, and the golden mean with a specific person in mind (e.g. "Yet you, Herbert, who understand such things, I And need not my advice when each day brings | New trials to test one's patience and the will $[\ldots]^{\prime \prime}$, and so on - these lines, I should add, are mine, not those of Jonson). It may simply be that Jonson never found the right moment for an extensive meditation on Lipsian notions of constancy and neo-Stoicism.

For present purposes, the broader significance of "Of Inconstancy" and its answer, beyond their inclusion in the forthcoming Oxford edition of Jonson's Poems, is that it is another example of a widespread literary practice. Neither Jonson nor Herbert are any less identifiably themselves for all that they have exchanged poems. On the other hand, neither exists in absolute isolation from the other: they are part of a community of friends, and texts. What stands out about this coterie of the first decade of the seventeenth century is the way in which the people involved record their sociability through the exchange of verse letters, satires, epigrams, and answer poems: Jonson was not always seeking patronage, sometimes his poems are genuine expressions of amicitias. This is quite different from the social circulation of verse in Oxford in the 1620s and 1630 s which, in many ways, is less intimate.

\section{III}

When Herrick was edited in the mid-twentieth century, the first edition of Hesperides was taken as the copy-text where possible (Martin 1956), whilst the full extent of Herrick's circulation in manuscript was not established by the editor. Rather, decisions about copy-text for known manuscript poems were based on the convenience of the Bodleian and British Libraries, rather than a strict analysis of textual traditions. Herrick was not alone in being edited in this 
way: Simpson edited Jonson's The Underwood from the 1640 Workes (Herford et al. 1925) - a decision that was repeated in the recent Cambridge edition; Ayton was edited from a couple of important manuscript collections, with miscellany copies ignored (Gullans 1963); even Henry King (edited by the manuscript scholar Margaret Crum) got the light touch and was primarily edited from the first printed edition (Crum 1966). Similarly, Helen Gardner, who was a formidable manuscript scholar, edited Donne from the 1633 Poems and a small group of related manuscripts (Gardner 1965: 1978). Hence the stemmatic analysis of manuscript traditions has been neglected, especially following some poor work by Leishman (1945) and Wolf II (1948).

Something approaching the full extent of the surviving manuscript evidence for Herrick was established by Peter Beal more than thirty years ago (Beal 1987. I: 527-66). What Beal revealed was a Herrick who was deeply involved in the manuscript culture of the 1620s and 1630s, and whose manuscript texts were variant from the printed texts in the Hesperides in significant ways. In particular, it became evident that Herrick did not necessarily revise in a straight progression through various stages, but that he might also revise by returning to his original papers and re-editing a poem in a completely different way, altering different lines, and hence creating two or more independent lines of transmission (Cain and Connolly 2011:Connolly 2012). The most recent Oxford edition of Cain and Connolly (2013) has addressed this by mapping the evolution of the poems in manuscript in a second volume, and providing some with stemmatic diagrams (though not all).

What follows is a discussion of the transmission history of a group of manuscripts for a specific problem text called "To his False Mistress" that has been attributed to Herrick, and for which Herrick wrote an answer "Goe perjured man". It is a poem for which the recent editors provided a stemmatic diagram and copy-text, both of which are at issue here, and in which they acknowledge that "there is no real evidence to suggest that Herrick wrote this poem" although they do observe that "Herrick might well have been involved with tweaking the attributed version" (Cain and Connolly 2013. II: 59). Nevertheless, their analysis fails to identify that point of transition from an original to an altered version and what those changes involved. As will be shown, although Herrick did not write the poem, he did tweak a total of four words. The rest of the manuscript history is one of scribal transmission where the variants were neither instigated by the original author nor by Herrick. Nevertheless, owing both to their reconstruction of the evidence and their adoption of a specific manuscript as their witness, the copy-text selected by the editors is variant by a further twelve words to the changes that were introduced by Herrick.

As will become evident, the reconstruction of scribal manuscript transmission without the survival of authorial papers poses a particular challenge to editorial practice because error is both endemic to the evidence and particular to the witness. Manuscript is different from print. When an editor selects a printed witness, removing the variants that were identified during stop-press correction, 
that choice reflects what several hundred or thousand people first read as the text. When an editor selects a scribal manuscript because there is no other witness, without removing the variants generated via scribal transmission, that text reflects what one person read and, in this instance, what twenty-one did not. The issue is both of philosophical and practical import.

The answer part of the exchange, sometimes known as "The Curse", is well attested as by Herrick in manuscript and was printed in the 1648 Hesperides: it survives in at least 59 manuscript copies (Beal 1987, HeR 49-107). "To his False Mistress", on the other hand, is not in Hesperides and survives in 22 known copies (Beal 1987. HeR 379-400): only eleven of which are copied with "The Curse" directly following. A further five witnesses have both "To his False Mistress" and "The Curse" present in the same miscellany, but at some distance from one another, and hence there stemmatic relationships belong to different traditions. One of the first issues that arises, therefore, is why "To his False Mistress" was excluded from Hesperides if it was written by Herrick.

The obvious and logical answer to this question is that Herrick's poem, "The Curse", is an answer poem, and that such poems were not usually written by the same person as the one that gave rise to the response. "The Curse" is also selfcontained, and it does not require knowledge of the other poem to appreciate its moral stricture. In other words, we are dealing with an example of social verse, similar to Jonson's answer poems, although it is not as convivial a response as the others. By removing the source poem, Herrick turns the direct trenchancy of the answer into an abstract and distanced comment: the "perjur'd man" could be any man and not simply the complainant of "To his False Mistress": by removing the cause of is animus, Herrick allowed conviviality to be restored.

The stemmatic diagram for "To his False Mistress" (see Figure 3) maps the transmission of the poem: it describes an early version of the text, and then two main lines of descent, and establishes that the attribution to Herrick occurs at the bottom of one line of descent of the revised version, and that both these copies descend from the same source (MS 9). For a valid attribution, an early state of the poem ought to have a clear association, and the further away that attribution is from the original copy, the less confidence we can have in the association (Bland 2013). As can be seen the initial state of the text (MS 1) has no attribution and, while "The Curse" is present in these miscellanies, it is does not follow on from "To his False Mistress" - in fact, in both cases, it occurs earlier in the collection as a whole. Those manuscripts that do have "The Curse" immediately following are marked with an asterisk.

Perhaps as useful from a textual point of view is the fact that the only variants between British Library Sloane MS 1446 and West Yorkshire Archives (Leeds) MS 156/237 are differences involving spelling and punctuation, but no substantive disagreements. Further, both copies agree that the poem was first written as three quatrains. As a copy-text, therefore, it represents the poem as Herrick received it (and thus as close as we can establish to the original author's intention), before Herrick made changes to suit his own purposes. As recorded in 


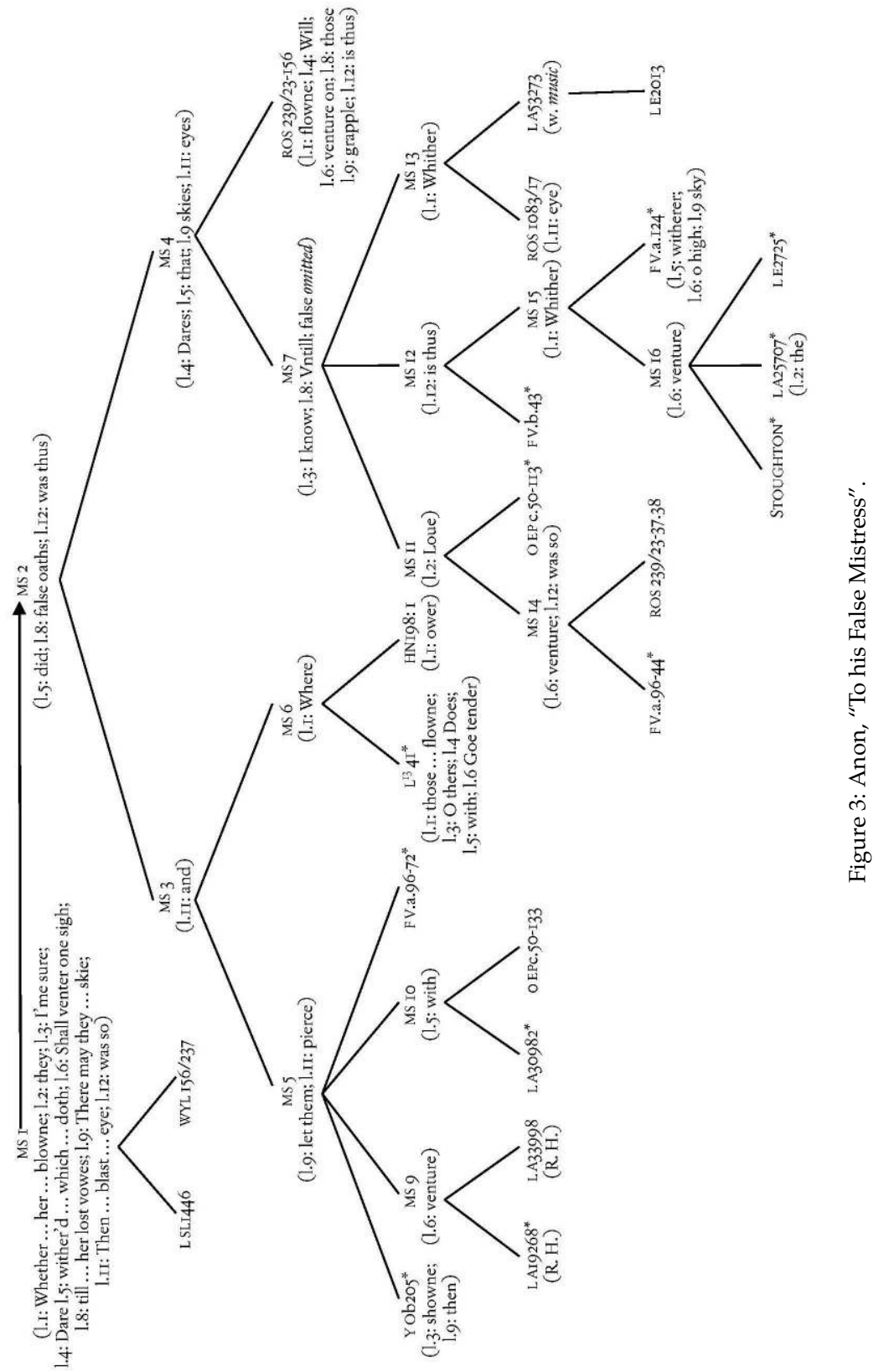


the Leeds manuscript, the text of the poem originally read:
Whether are all her false oathes blowne?
Or in what Region doe they liue?
I'me sure no place, where fayth is knowne
Dare any harbor to them giue:

My wither'd hart which loue doth burne

Shall venter one sigh with the winde,

And neuer back againe returne

Till one of her lost vowes it finde.

There may they wrastle in the Skye,

Till they doe both one lightning proue;

Then falling lett it blast her eye,

That was so periur'd in her loue.

When he got hold of the poem, Herrick altered the archaic "doth" in line five to "did", changing the present into the past; the "lost vowes" in line eight once again became the "false oathes" of line one; and in the final line "so" was altered to "thus", changing the egregious emphasis with the rhetoric of an argument. Overall, the changes shift the sentiment from one of present suffering to past hurt, more clearly enabling Herrick to level the accusation of insincerity. To argue, as the Oxford editors have implicitly done, that Herrick then made a further twelve changes to such a short poem, none of which are indicative of a more refined intelligence revising it, is difficult to credit as plausible.

The critical reading to determine is "venter" (to sell) in line 6 and its variant "venture" (to invest, put forth): this occurs on both sides of the MS 2 line of descent, at stages independent of one another, and simply reflects the scribal habit of substituting the more familiar word. This is not problematic because it is the logical variant: what is important about "venture" is that once it has occurred there is no way back to "venter". It would, in other words be much harder to argue that three separate scribes changed "venture' to "venter" than the other way round, which confirms the primacy of "venter" as the original reading. One other manuscript reads "tender", a variant that would not be repeated independently because it involves a more significant change. There are a couple of other independent agreements that are straightforward in their cause, but for present purposes what matters for reconstructing the stemma is that "venter/venture" is removed from the primary analysis beyond placing "venter" at the top of the tree. When this is done, the line of recension can be established fairly easily.

All stemma involve an element of critical taste in their estimation of the facts: this is particularly true when determining the source and direction of the primary readings before scribal changes took place (Love 1984): for instance, did line 3 first read "I'm sure" or "I know": the later is both more emphatic and prosaic; to be "sure" means that the possibility of doubt has been entertained and examined before a secure knowledge is asserted; the claim to "know" requires 
no such critical assessment of the facts. For that reason, "I'm sure" was preferred as the primary reading as was "which" over "that" in line 5: these decisions subsequently meant that the link between what became the MS 1 group and the source did not depend on any other line of recension, and hence opened up the possibility of that group being the original version. In stemmatic analysis, simplicity is the greatest virtue.

If we begin with the larger group of manuscripts descending from MS 2, the reading "I'me sure" occurs in all the manuscripts on the left side, as well as in Rosenbach MS 239/23 p.156, and all but one of those on the left side read "Dare" in line 4, while the other manuscript reads "Will". George Morley's text in Westminster Abbey MS 41 is variant in both cases, reading "Others" and "Does": the latter an understandable palaeographical misreading of "Dare". What marks off the "Will" manuscript, Rosenbach MS 239/23 p.156, as belonging on the right-hand side is that it shares the readings "that", "skies" and "eyes" with the "I know" manuscripts of MS 4. It is in other respects highly variant and we can only assume that we have lost part of the chain of evidence that generated such variants as "grapple" for "wrestle" in line 9. This was the copy-text chosen by the Oxford editors despite what was so clearly an erroneous reading.

On the left-hand side, descending from MS 3, the equally variant MorleyWestminster manuscript is linked by the shared reading "And" for "Then" in line 11 and to Huntington MS 198 part 1 by the reading "Where" for "Whither" in line 1. Once again the extent of the Morley-Westminster variants suggests that we are missing some intermediary witnesses that might account for how that text became as corrupt as it did: in this particular instance the textual history of "The Curse" might provide some of the missing clues.

Once the two oddities are accounted for, the remaining manuscripts present few difficulties. On the right hand side, descending from MS 4 through MS 7, all the remaining eleven manuscripts are linked by reading "I know" for "I'm sure" in line 3, while expanding "till" to "Vntill" and omitting "false" from "false Oathes" in line 8. Three of these manuscripts, via MS 11, substitute "Loue" for "faith" in line 2: all read "was" in line 12, with one manuscript preserving "was thus", and two reading "was so" via MS 14, two of these witnesses are also in quatrains; five of the other manuscripts are grouped by "is thus" in the final line via MS 12, while the other three retain "was thus" but substitute "Whither" for "Whether" in line 1 via MS 13. Within the "is thus" tradition, the remaining witnesses independently substitute of "Whither" for "Whether" and "venture" for "venter".

The final six manuscripts on the left-hand side, descending from MS 5, also form a coherent group. They are all linked by reading "pierce" for "blast" and "let them" for "may they"; two of the manuscripts read "venture" for "venter" (this is why this reading needed to be excluded from the initial analysis) and two read "with" for "which" in line 5. Of the remaining two manuscripts Yale University Osborn MS b205 has two variants that suggest that again we may be missing an intermediary, whilst Folger MS V.a.96 p.72 turns out to be the best 
text of this tradition, and it includes capitalisation and italics.

The most significant other line of descent is MS 9 that has the only two manuscripts that attribute "To his false Mistress" to Herrick: these are linked by the reading "venture": what is important about this group is that the attribution to Herrick is demonstrably late; it descends from a common source, and it only occurs at this point across the entire stemmatic tradition. Further, there is no other attribution to Herrick on the right-hand side that would suggest the attribution derives from the top of the tree. On the other hand, the manuscripts marked with an asterisk occur on both sides of the stemma, suggesting that "The Curse" was circulated with "To his False Mistress" from the outset.

When the stemma was first drawn the MS 1 group were placed hanging in the middle, between the two more extended groups. What was evident, however, was the unusual nature of two of the variants and by the fact that neither of the manuscripts circulated directly with "The Curse" (although both have it elsewhere in their volumes). This was suggestive. Elsewhere in this analysis, it has implicitly been suggested that the old fashioned variant is probably earlier and the more current word later (Bland 2010. 177-82): hence "venter" is earlier than "venture" and "Whether" (as used) earlier than "Whither". By the same logic, "doth" ought to be earlier than "did" and it is difficult to see why a later scribe would deliberately introduce an old-fashioned form. Equally, "lost vowes" is an unusual substitution for "false oathes" as it has neither a palaeographical cause nor a memorial one, and it cannot be argued to be the "more common word". The most likely explanation for such a variant is revision.

The issue is therefore one of direction: while Herrick might have revised "was thus" to "was so", it is unlikely that he would have revised "did" to "doth". Further, given the circulation of the MS 2 tradition, it seems unusual that the MS 1 tradition did not circulate as widely. If, on the other hand, the MS 1 readings represent the original version of the poem, then what happened becomes explicable: Herrick received an early version of "To his False Mistress", tweaked the text, and circulated it with his answer, "The Curse". When it came to printing Hesperides, he simply excluded "To his False Mistress" because he knew he was not the author of that poem, and that "The Curse" could stand without it.

One final comment: it is possible to reconstruct the stemma in another way. The issue is that if "lost vowes" were a sign of revision, then "pierce" for "blast" could be as well. This would involve swinging the left-hand MS 3 side out to the right and up across the top line. To do so, we would have to argue that the poem was revised not once, but twice: first changing "Then" to "And" in line 11, and next changing "may they" to "let them" in line 9 and "blast" to "pierce" in line 11. If this were the case, then Folger MS V.a.96 p.72 would require no modification other than a small adjustment to its punctuation as the final revised copy-text. This is not an option that the Oxford editors discussed. The hesitation about doing so is that we are clearly missing something from the manuscript tradition to account for the witnesses we have. Against this doubt, one has to acknowledge that "pierce" could be a further revision by Herrick. 


\section{IV}

It was observed at the outset of this article that the conjunction of the textual histories of different authors in a single miscellany could be informative about how and when the various texts were circulating. In the case of MS 156/237 from the West Yorkshire Archive in Leeds, we have a late version of Jonson's "A Poem sent me by Sir William Burlase" and the earliest version of "To his False Mistress". The sequence in which they are found has a great many poems by William Strode and Thomas Carew, a couple by Aurelian Townshend, one by John Grange, a few poems by Donne and a scattering of poems by Jonson written at different stages of his career. The immediate sequence that follows after a copy of Jonson's "Eupheme", written in 1633, involves three poems by Carew, one by Townshend, three more by Carew, then "To his False Mistress" followed by lines from Jonson's "Satyricall Shrub" and the song from Epicoene, and then again Carew. This clearly points to someone in the Jonson-Carew nexus as being responsible for the poem. In British Library Sloane MS 1446, "To His False Mistress" also follows on from three poems by Carew, but of these it is only the last, "To T. H. a Lady resembling my Mistress", that is the same. In other words, the source of the poem is someone associated with Carew.

The Burlase poems do not occur in the Sloane manuscript, and they appear some twelve pages on from "To his False Mistress" in the Leeds material. In between are a medley of poems by Strode, William Herbert, Townshend and Donne. That section clearly involves a different, looser set of underlying papers than those in which "To his False Mistress" is found. For the record, "The Curse" occurs much earlier, at the start of the volume, among a sequence of poems by Henry King and Carew, mixed in with a couple of poems by Donne. There is no Jonson material in that part of the miscellany. The volume was prepared by a cousin of Sir John Reresby of Thribergh Hall.

Although it is evident that "To his False Mistress" is not by Herrick, that does not mean it ought to be excluded from a scholarly edition of his verse. "To his False Mistress" and "The Curse" share a similar, if more detached, relationship as the Burlase-Jonson exchange; the difference is the tone of the answer and the fact that the we do not know the author of the poem that Herrick attacked, although we do know the circle from which it emerged. In that sense "To his False Mistress" joins the massed ranks of anonymous manuscript verse texts of the early seventeenth century (North 2003).

The story, however, does not quite end with the de-attribution of "To his False Mistress" from the canon of Herrick's verse. Herrick was directly or indirectly responsible for the existence of twenty of the twenty-two surviving copies for the poem that only became well known because he circulated it with his answer. Hence, we need to understand "The Curse" from the perspective of both its history as an answer, and as a poem that circulated separately in its own right. As 48 out of 59 copies of "The Curse" exist without direct connection to "To his False Mistress" it is evident that Herrick continued to revise that poem 
independently of the poem with which he first circulated it. That is a larger question, summarized but not fully answered by the Oxford editors and, again, it is one that raises further and separate questions as well as editorial issues.

For the present, it is enough to have demonstrated the ways in which stemmatic analysis can be useful in resolving issues of origin and authorship. All stemma are maps of social networks (Bland 2013). Many of the manuscripts discussed have known compilers, and those people were often members of Oxford and Cambridge colleges, or the Inns of Court, and had extended familial relationships. It would take too long here and now to begin to describe and detail all those connections, but what such an analysis does is invite that kind of historical reconstruction. The more we build up maps of such networks, the more subtle our understanding of scribal transmission will become. When we use terms such as scribal networks, community, and conviviality, we need to recognize that they are not abstractions and that the history of specific contexts will leave traces in the textual and archival records that most interest us. Part of the problem is unlocking the information in a way that allows us to understand more acutely what the primary evidence is, and what it represents. Further studies of other texts will no doubt elucidate much that remains unstudied and unclear, especially with regard to the anonymous and doubtfully attributed texts of the period.

\section{Bibliography}

Beal, Peter, ed., 1980. Index of English Literary Manuscripts I: 1475-1625. London: Maunsell.

1987. Index of English Literary Manuscripts II: 1625-1700. London: Maunsell.

- 1998. In Praise of Scribes. Oxford: Oxford University Press.

Bevington, David, Ian Donaldson, and Martin Butler, eds., 2013. The Cambridge Edition of the Works of Ben Jonson. Cambridge: Cambridge University Press.

BLAND, MARK B., 1998. "Jonson, Biathanatos and the Interpretation of Manuscript Evidence." Studies in Bibliography 51, pages 154-82.

Blackwell.

2010. A Guide to Early Printed Books and Manuscripts. Chichester: Wiley

2013. "Stemmatics and Society in Early Modern England." Studia Neophilologica 85, pages 1-20.

Cain, Tom and Ruth Connolly, eds., 2011. Lords of Wine and Oile: Community and Conviviality in the Poetry of Robert Herrick. Oxford: Oxford University Press. 
2013. The Complete Poetry of Robert Herrick. Oxford: Oxford University Press.

Connolly, Ruth, 2012. "Editing Intention in the Manuscript Poetry of Robert Herrick." Studies in English Literature 52, pages 69-84.

Crum, Margaret, ed., 1966. The Poems of Henry King. Oxford: Oxford University Press.

Gardner, Helen Louise, ed., 1965. The Elegies and the Songs and Sonnets [of John Donne]. Oxford: Oxford University Press.

\section{Press, 2nd edition.}

Gullans, Charles B., ed., 1963. The English and Latin Poems of Sir Robert Ayton. Edinburgh: Edinburgh University Press, 2nd edition.

Hart, E. F., 1956. "The Answer-Poem of the Early Seventeenth Century." N.S.(7), pages 19-29.

Herford, Charles Harold, Percy Simpson, and Evelyn Simpson, eds., 1925. Ben Jonson. Oxford: Oxford University Press.

Leishman, J. B., 1945. "You Meaner Beauties of the Night. A Study in Transmission and Transmogrification." The Library IV(26), pages 99-123.

Love, Harold, 1984. "The Ranking of Variants in the Analysis of Moderately Contaminated Manuscript Traditions." Studies in Bibliography 37, pages 39-57.

Moore Smith, George Charles, 1923. The Poems English and Latin f Edward, Lord Herbert of Cherbury. Oxford: Oxford University Press.

Nixon, Scott, 1999. "'Aske me no more' and the Manuscript Verse Miscellany." English Literary Renaissance 29, pages 97-130.

North, Marcy L., 2003. The Anonymous Renaissance: Cultures of Discretion in Tudor-Stuart England. Chicago (IL): University of Chicago Press.

Wolf II, EdwiN, 1948. "“If shadows be a picture's excellence': An Experiment in Critical Bibliography." PMLA 63, pages 831-57. 